\title{
Relations between preservice teachers' views about nature of science and sense of efficacy
}

\author{
Şenol Şen ${ }^{1, *}$ \\ ${ }^{1}$ Hacettepe University, Department of Mathematics and Science Education, 06800, Beytepe, Ankara, \\ Turkey
}

\begin{abstract}
The purpose of this study was to investigate the relations between preservice teachers' views about nature of science and sense of efficacy. The study group was comprised of 72 female and 24 male preservice teachers and their average age were 19.53 (range 18 to 35), and 20.75 (range 18 to 52), respectively. The Nature of Science View Scale (NOSvs) and the Teachers' Sense of Efficacy Scale (TSES) were used as data collection tools. The Pearson product-moment correlation analysis was conducted to explore the relations between pre-service teachers' views about nature of science and sense of efficacy. According to the correlation analysis, it was determined that there is a significant correlation between preservice teachers' views about nature of science $(\mathrm{p}=.000$ and $\mathrm{r}=.403$, for the total score) and sense of efficacy.
\end{abstract}

\section{Introduction}

The nature of science is defined as science epistemology and as values or beliefs available in the essence of the development of science or scientific knowledge as the way of knowing [1] although there is no consensus on a specific definition. The perception of the nature of science has three basic components: a) understanding that science cannot find answers to all questions, b) understanding that inquiry in science is based on logic and that it is experiment-based but that it involves exhibiting imagination and explanations, c) understanding the social and political aspects of science [2]. Lederman, Abd-El-Khalick, Bell, and Schwartz [3] and Ryan and Aikenhead [4] state that teachers' perceptions of the nature of science and their practice in the classroom influence their students' views on science. Paying attention to teachers' comprehension of the nature of science-inspired studies aiming to improve and evaluate their comprehension of the nature of science [5]. Various studies $[6,7,8]$ made attempts to determine the correlations between teachers' views and their instructional practice. However, it was found that the correlations between the two were more complicated than they were considered to be $[9,10]$. On the other hand, one of the important motivational factors shaping the effectiveness of teachers in their classrooms is teachers' self-efficacy [11]. Teachers' self-efficacy is their belief in knowing how their students learn better and in how much they can influence them in learning environments [12]. Teachers' behaviors are correlated to such variables as levels of their efforts, enthusiasm, planning, resolution, creativity, willingness to work with difficult

\footnotetext{
* Corresponding author: schenolschen@gmail.com
} 
students and devotion to teaching [13]. In addition, they are the motivational structures directly influencing the classroom output [11]. Review of literature demonstrates that studies trying to determine teachers' views on the nature of science are available $[1,4,5$, $14,15,16,17,18]$. In the same vein, there are also studies analyzing the development of teachers' self-efficacy $[11,19]$. Yet, the fact that the number of studies analyzing the correlations between pre-service teachers' self-efficacy belief and their teaching of the nature of science was small $[20,21,22]$ was the justification for conducting this current study.

\subsection{The aim of the study}

NOS combines various fields of science such as science history, sociology, psychology and philosophy, and consists of answers to questions such as what science is, how it works, how scientists work, and what the impact of social and cultural contexts on science is [23]. Hanson [24] stated that one of the factors effected on teachers' sense of self-efficacy, which had not been investigated, was understanding of the nature of science. These two structures had been examined independently in different studies but the relations between these two variables had not been analyzed. Chun and Oliver [20] asserted that there is no a consensus on whether there is a relationship between in-service and preservice teachers' beliefs about the nature of science and teacher self-efficacy beliefs. Therefore, the purpose of this study was to investigate the relations between preservice teachers' views about nature of science and sense of efficacy.

\section{Method}

\subsection{Study group}

The study group was comprised of 72 female and 24 male preservice teachers with an average age of 19.53 (range 18 to 35), and 20.75 (range 18 to 52), respectively. The scales were conducted to preservice teachers from five different disciplines named chemistry education, primary education, mathematics education, English language teaching and German language teaching. They came from families of differing socio-economic levels. Preservice teachers were participated voluntarily in the study.

\subsection{Data collection tool}

The nature of science view scale (NOSvs) and the teachers' sense of efficacy scale (TSES) were used as data collection tools. The Nature of Science View Scale (NOSvs) was developed by Temel, Şen, and Özcan [25]. The scale included 36 items (26 items were positive and 10 items were negative). The NOSvs had five subscales named Definition and Limits of Science (DLS), Scientific Method (SM), Theory-laden and Subjective Nature of Science (TSNOS), Socio-cultural Embeddedness of Science (SES), and Tentative and Empirical Nature of Science (TENOS). Each item is scored on a 5-point Likert scale with 1 = Strongly Disagree and 5 = Strongly Agree. The Cronbach's alpha coefficient for internal consistency was .70 for the subscale DLS, .79 for the subscale SM, .80 for the subscale TSNOS, .75 for the subscale SES, and .84 for the subscale TENOS.

The second data collection tool of the study was the Teachers' Sense of Efficacy Scale developed by Tschannen-Moran and Hoy [26]. The scale was consisted of 12-items divided into three sub-scales, which are named as Efficacy for Instructional Strategies (EIS), Efficacy for Classroom Management (ECM), and Efficacy for Student Engagement (ESE). 
Each item is scored on a 9-point Likert scale with $1=$ nothing and $9=$ a great deal. The Cronbach's alpha coefficient for internal consistency was .93 for the entire scale, .86 for the subscale EIS, .84 for the subscale ECM and .82 for the subscale ESE. In this study, only the total score of TSES was used for the correlational analyses.

\subsection{Analyses of the data}

The Pearson product-moment correlation analysis was used to explore the relations between pre-service teachers' views about nature of science and sense of efficacy.

\section{Findings}

The findings related to the Pearson product-moment correlation analysis were given in Table 1.

Table 1. Findings of Pearson product-moment correlation analysis

\begin{tabular}{|c|c|c|c|c|c|c|c|}
\hline \multicolumn{8}{|c|}{ Correlations } \\
\hline & & DLS & SM & TSNOS & SES & TENOS & NOSvs \\
\hline \multirow[t]{3}{*}{ TSES } & Pearson Correlation & .331 & .208 & .285 & .102 & .227 & .403 \\
\hline & Sig. (2-tailed) & .001 & .042 & .005 & .324 & .026 & .000 \\
\hline & $\mathrm{N}$ & 96 & 96 & 96 & 96 & 96 & 96 \\
\hline
\end{tabular}

The results of the correlation analysis revealed that there is a medium positive, significant correlation between TSES and NOSvs $(r=.403, n=96, p<.05)$. When the relations were examined between TSES and subscale of NOSvs, there is a significant and medium correlation between TSES and DLS and significant and small correlations between TSES and SM, TSES and TSNOS, TSES and TENOS. However, there was no significant correlation between TSES and SES $(p>.05)$. In addition, it may be said that approximately $16.2 \%$ of the variance in preservice teachers' TSES scores was explained by NOSvs scores.

\section{Discussion and conclusions}

In the current study, the relations between preservice teachers' views about nature of science and sense of efficacy were determined with the Pearson product-moment correlation analysis. According to the results of correlation analysis, it was determined that preservice teachers' views about nature of science $(\mathrm{p}=.000$ and $\mathrm{r}=.403$, for the total score) displayed a significant correlation with sense of efficacy. In addition, preservice teachers' sense of efficacy was associated with DLS, SM, TSNOS, and TENOS. However, according to the correlation analysis, there was no significant correlation between sense of efficacy and SES.

A review of relevant literature indicates that the number of studies concerning the correlations between prospective teachers' sense of efficacy and their views about the nature of science is quite small [20,21, 22]. The study conducted by Mihladiz and Doğan [22], for instance, points out that preservice teachers' inadequacies in teaching the nature of science stem from their weak self-efficacy beliefs. In another study, Chun and Oliver [20] found that there were highly positive correlations between teachers' self-efficacy beliefs 
and their views on the nature of science. Abell and Smith [27] contended that there were high correlations between teachers' views of the nature on the nature of science and their beliefs about learning and teaching. Hanson [24] states that increase in teachers' knowledge about the nature of science will lead to increase in their self-efficacy beliefs in teaching the nature of science. The researcher also state that understanding the content of the nature of science will contribute to teachers' self-efficacy in teaching science [24].

This study found that there were medium level correlations between preservice teachers' self-efficacies and their views on the nature of science. Therefore, the studies to be conducted in the future will help to explore the correlations exactly. Using a study group of teachers would also contribute significantly to the literature.

\section{References}

1. N. G. Lederman, J. Res. Sci. Teach. 29, 331 (1992)

2. American Association for the Advancement of Science. Science for all Americans (New York: Oxford University Press 1990)

3. N. G. Lederman, F. Abd-El-Khalick, R. L. Bell, R. S. Schwartz, J. Res. Sci. Teach. 39, 497 (2002)

4. A. G. Ryan, G. S. Aikenhead, Sci. Educ. 76, 559 (1992)

5. F. Abd-El Khalick, N. G. Lederman, Int. J. Sci. Educ. 22, 665 (2000)

6. R. A. Duschl, E. Wright, J. Res. Sci. Teach. 26, 467 (1989)

7. V. Mellado, Sci. Educ. 6, 331 (1997)

8. V. Mellado, M. L. Bermejo, L. J. Blanco, C. Ruiz, Int. J. Sci. Math. Educ. 6, 37 (2007)

9. N. G. Lederman, M. Druger, J. Res. Sci. Teach. 22, 649 (1985)

10. N. G. Lederman, D. L. Zeidler, Sci. Educ. 71, 721 (1987)

11. D. Pendergast, S. Garvis, J. Keogh, Aus. J. Teach. Educ. 36, 4 (2011)

12. A. B. Dellinger, J. J. Bobbett, D. F. Olivier, C. D. Ellett, Teach. Teach. Educ. 24, 751 (2008)

13. M. Tschannen-Moran, A. W. Hoy, W. K. Hoy, Rev. Educ. Res. 68, 202 (1998)

14. K. Balc1, The information literacy success of prospective teachers, the relationship between the level of computer self-efficacy and information literacy self-efficacy (Unpublished master's thesis, Firat University, Elazığ, Turkey 2013)

15. C. Dönmez, S. Uslu, J. Turk. Educ. Sci. 11, 42 (2013)

16. R. A. Duschl, Restructuring Science Education: The Importance of Theories and Their Development (Teachers College Press, New York 1990)

17. G. Kaya, G. Çakmakçı, Fen kavramlarıyla ilişkilendirilmiş doğrudan yansıtıcı yaklaşımın ilköğretim ögrencilerinin bilimin doğası hakkındaki görüşlerine ve akademik başarlarına etkisi [The effect of Reflective Explicit Activity-based Approach associated with science concepts on primary school students' views on the nature of science and on academic achievement] (X. Ulusal Fen Bilimleri ve Matematik Eğitimi Kongresi, Niğde 2012).

18. N. G. Lederman, Nature of Science: Past, Present, and Future. In Abell, S. K., \& Lederman, N. G. (Eds.), Handbook of research on science education (Lawrence Erlbaum Associates, London 2007).

19. B. G. Swan, K. J. Wolf, J. Cano, J. Agric. Educ. 52, 128 (2011)

20. S. Chun, J. S. Oliver, A quantitative examination of teacher self-efficacy and knowledge of the nature of science (Paper presented at the annual meeting of the Association for the Education of Teachers in Science, Akron, OH, 2000). 
21. G. Mihladiz, Investigation of the preservice science teachers? Pedagogical content knowledge about the nature of science (Unpublished doctoral dissertation, Gazi University, Ankara, Turkey 2010).

22. G. Mihladız, A. Doğan, Hacet. U. J. Educ. 32, 380 (2017)

23. W. F. Mccomas, J. K. Olson, International Science Education Standards documents. In WF. Mccomas (Ed.) The nature of science in science education rationales and strategies (The Netherlands: Kluwer Academic Publishers 2000)

24. D. L. Hanson, Personal definitions of science and the self-efficacy and classroom practice of elementary school teachers (Unpublished doctoral dissertation, Indiana University, Bloomington 2006).

25. S. Temel, Ş. Şen, Ö. Özcan, Res. Sci. Technol. Educ. 36, 55 (2018)

26. M. Tschannen-Moran, A. W. Hoy, Teach. Teach. Educ. 17, 783 (2001)

27. S. K. Abell, D. C. Smith, Int. J. Sci. Educ. 16, 475 (1994) 